\title{
Effects of Over-Scheduled involvement in Co-Curricular Activities on the Academic Achievement of Secondary School Students in Kohat Division, Pakistan
}

\author{
Qaiser Suleman \\ Ph.D (Education) Scholar, Institute of Education \& Research, \\ Kohat University of Science \& Technology Kohat, Khyber Pakhtunkhwa, Pakistan \\ Email: Look_for_reality@yahoo.com \\ Dr. Termit Kaur Ranjit Singh \\ (Corresponding Author) \\ Senior Lecturer, \\ Lead Trainer, ICT in Education Resource Distribution Center, UNESCO Bangkok \\ School of Educational Studies, \\ Universiti Sains Malaysia \\ 11800 Penang \\ Zeeshan \\ M.Phil Scholar, Department of Islamic Studies \& Research, \\ University of Science \& Technology Bannu, Khyber Pakhtunkhwa, Pakistan \\ Email: zeeshankbk@gmail.com
}

Doi:10.5296/ijld.v4i3.5973 URL: http://dx.doi.org/10.5296/ijld.v4i3.5973

\begin{abstract}
The purpose of the current research paper was to examine the effects of over-scheduled involvement in co-curricular activities on the educational attainment of students at secondary school level in Kohat Division. The target population of the study was comprised of secondary school students in Kohat Division. Fifty students of Grade 10 from Government High School (Boys) Khurram (Karak) were taken as sample using simple random sampling. The study was experimental in nature and therefore, "Pre-test-Post-test Equivalent Groups Design" was used. The students of experimental group were involved in co-curricular activities for 40 minutes in school and 2 hours after school time. The students of the control group were involved for 40 minutes in school only. Data was collected though pre-test and post-test technique. In order to analyze the data, statistical tools i.e., mean, standard deviation and t-test were used. The current research findings indicate that there is significant negative effect of over-scheduled involvement in co-curricular activities on the educational attainment of students at secondary school level. Past research studies reveal that involvement in co-curricular activities is directly proportional to the achievement level of the students. There is a strong connection between student's participation in co-curricular activities and excellent academic performance. The current study negates the findings of past research studies regarding involvement in co-curricular activities and students' academic achievement. The current paper shows that how over-scheduled involvement in co-curricular activities affect the academic performance of students negatively. Therefore the findings of this research study will prove more fruitful and productive in enhancing student's educational achievement at secondary school level.
\end{abstract}


Keywords: Effects; Co-curricular Activities; Over-Scheduled Involvement; Academic Achievement; Secondary School Students

\section{INTRODUCTION}

No doubt, co-curricular activities are necessary for the mental, physical, moral and social development of an individual. Participation in such activities results in higher academic achievement and good physique. Co-curricular activities ensure a balanced and nourishing personality development. They make children well-adjusted physically, mentally, emotionally and socially. These activities are also useful in moral training. Children get opportunities to learn the great values of self-discipline, moderation, brother-hood, true democracy and co-operation. Every activity possesses some rules and regulations. During co-curricular activities students follow these rules and regulations and they become well-disciplined. Leadership qualities are also shaped in students in such activities. These activities set aside children from getting involved in destructive and negative activities as their spare time is spent in constructive and positives activities.

Majority of the scholars advocate that extraordinary involvement in physical co-curricular activities has a significant positive effect on the educational outcomes of student. According to Hollar et al. (2010) and Shephard et al (1994), learning and grades are enhanced by the increased participation in physical activities. Similarly, other scholars believe that children who spent a smaller amount of time in the academic engagement and more time in physical activities during the school day have no negative effects on their academic success or progress (Coe et al., 2006; Ahamed et al., 2007; Dollman et al., 2006; Sallis, et al., 1999). Field (2001) concluded that students who spent more time in sports, they achieved higher GPA. According to Coe, et al (2006), involvement in vigorous physical activities may improve learning process. Allison (1979) noted that students who participated in co-curricular activities not only performed better academically as compared to those students who are not involved but other aspects of their personality are also developed in these activities. Only a few cognitive factors i.e., self-confidence, self-esteem, social teamwork, and leadership abilities are affected. Through co-curricular activities, certain features of students' academic learning merge into personal actions.

\section{REVIEW OF RELATED LITERATURE}

Co-curricular activities refer to the activities that are necessary for the balance personality of children. Formerly, the term "Extra-Curricular Activities" was used for such activities but now they are not regarded as extra because the word "Extra" is referred to something "Unnecessary" or Unimportant". The aim of education is not to communicate some factual knowledge to the learners but to make sure his overall development of balanced personality. A child needs mental, physical, social, moral and emotional development. All these requirements of a child are not possible only with book reading. They require particular activities to meet these requirements. That is why those activities that help in the physical, moral, social and civic development of the child are called co-curricular activities. For examples, debating, athletics, sports, scouting, excursions etc (Katozai, 2005). Therefore, co-curricular activities refer to a series of activities that are associated with institutional programmes necessary for the overall development of students outside the course subjects for examination scheduled (Mehmood, et al., 2012). The examples of these activities are sports, choir practice, debate, music lessons, religious study, charitable fund raising, theatricals, science clubs, as well as hobbies like gardening, crafts, dancing and home economics (Marais, 2011). Hence, co-curricular activities provide with extra opportunities for personal growth, 
skill development, self-discipline, leadership skills, honesty, unity, brotherhood, creativity, mutual cooperation and fun etc. In short, those activities through which an individual develops a balance personality and adopts different skills necessary for his balanced personality I.e., self-discipline, leadership skills, unity, brotherhood, mutual cooperation, competition etc .

According to Wagner (1999), co-curricular activities promote personal accomplishments and the development of interpersonal skills. Young people who get involved in such activities have chances to undertake significant functions and responsibilities. Marsh \& Kleitman (2002) examined whether involvement in co-curricular activities affects academic achievement even when student's ability, school, personal and family characteristics and also other various aspects are controlled. They concluded that participation of the students in such activities for a longer time causes higher scores, selection of difficult courses, much involvement in homework, and earning of higher final degree even on the part of students when other elements are controlled (Fredricks and Eccles, 2006). Darling et al (2005) investigated the achievement level of the students who participated in co-curricular activities with those who did not take part in such activities and concluded that students showed higher academic ambitions, better academic attitudes as well as achieved higher scores as compared to those who did not participate in extracurricular activities in any way. Gardner, et al. (2008) found that involvement in planned activities is positively linked with academic and civic success as well as associated with occupational success to some extent in adolescences. Reeves (2008) concluded that participation in co-curricular activities causes desirable behaviours, enhanced attendance and excellent academic performance on the part of student.

But unfortunately, here the situation is quite different. Now-a-day, cricket has become the most popular game in the world especially in Pakistan. Every child and grown up people like it. Due to its popularity, children are found always engaged in playing the same game or watch on television. They arrange cricket tournament at village, tehsil and district level. It is generally observed that the students in rural areas pay their full attention on cricket. They do not pay their attention on their studies. That's why they have lack of time to do homework assigned by the teachers. Consequently, their overall academic performance is affected negatively and show unsatisfactory results in their examinations. According to Ara \& Saleem (n. d), the attitude of the headmasters and teachers was found against the co-curricular activities as it was only the waste of time and efforts. They were found in favour of academic activities. According to Thompson (2008), the level of commitment is much more important than the specific activity. Over-scheduling not only can affect the academic achievement and level of commitment but it can also affect students physically and emotionally. Consequently, students become victim of stress, fatigue and tiredness. Cooper, et al. (1999) studied the relative impacts of time spent in different activities after school time, including school-sponsored extracurricular activities, employment, watching of television and homework. They found a positive impact of involvement in extracurricular on achievement test scores. Conversely, there is a threshold for this effect at the highest level of involvement in extracurricular; they noticed a precipitous decline in test scores. Reeves (2008) stated that teachers and parents might feel fear that the students will not pay their attention on academic activities if they get involved too much in various activities after school time. To attend too many training activities, meetings, and other practices can interrupt homework time. When students get over-scheduled, they might be spreading themselves too thin, which will cause to give less time to their studies and preparation for class.

According to Katozai (2005), the functions of co curricular activities are given below: 
- Co-curricular activities ensure a balanced and nourishing personality development. They make children well-adjusted physically, mentally, emotionally and socially.

- Co-curricular activities are useful in moral training. Children get opportunities to choose the right and to learn the great values of self-discipline and moderation. Through the community life of games and activities, the child learn an inner discipline which abides with the child as a directing and restraining influence when he is away from the school.

- Students realize the relation of the society to the individuals and of the individual to the society by participating in co-curricular activities. The students become a member of the group and therefore he learns universal brother-hood, true democracy and co-operation.

- The school is considered as a training ground for democracy. Therefore it should be organized and administered on democratic lines so that it may prove beneficial for students to become a good citizen and to develop civic sense.

- Co-curricular activities help in developing a sense of cooperation among the students. They study, work, play and visit together and co-operate each other. So a spirit of co-operation is produced in them.

- Co-curricular activities maintain not only the physical health but also the mental health of the students. By doing regular exercise their bodies become healthy. Their mental health is also maintained because a sound body has a sound mind.

- Every activity possesses some rules and regulations. During co-curricular activities students follow these rules and regulations and they become well-disciplined.

- Most of co-curricular activities are carried out in the form of teams and group which require a leader. So leadership qualities are shaped in students.

- During co-curricular activities students attend different matches and compete with each other in order to win these matches. Thus they develop a sense of competition which is very beneficial for their future life.

- Co-curricular activities save children from getting involved in destructive and negative activities as their spare time is spent in constructive and positives activities.

\section{PURPOSE OF THE STUDY}

The current research paper was designed to examine the effects of over-scheduled involvement in co-curricular activities on the academic achievement of the secondary school students in Kohat Division, Pakistan.

\section{HYPOTHESES OF THE STUDY}

The following two null hypotheses were developed:

- There is no significant difference between the performance of control and experimental groups on pre-test.

- There is no significant difference between the performance of control and experimental groups on post-test. 


\section{MATERIALS AND METHOD}

\section{Participants}

The target population of the study was the secondary school students studying in public sector in Kohat Division, Pakistan. As the study was experimental in nature therefore only fifty students of Grade 10 studying in Government High School (Boys) Khurram, Karak were taken via simple random sampling for experimental treatment.

\section{Delimitations of the Study}

Due to experimental nature of the study, the study was delimited to students of Grade 10 of Government High School (Boys) Khurram, Karak only. The study was further delimited to the subject of Chemistry published by Khyber Pakhtunkhwa Textbook Board Peshawar and the following 4 chapters were taught during experiment:

Table 01: Showing the four units of Class 10 Chemistry

\begin{tabular}{llll}
\hline S. No & Chapters & S. No. & Chapters \\
\hline $\mathbf{0 1}$ & Hydrogen & $\mathbf{0 3}$ & Carbon and Its Compounds \\
$\mathbf{0 2}$ & Nitrogen and Oxygen & $\mathbf{0 4}$ & Sulphur and Its Compounds \\
\hline
\end{tabular}

\section{Research Design}

The study in hand was experimental type and that is why "Pre-test-Post-test Equivalent Groups Design" was considered suitable. Through this design, participants of the research study are allocated to experimental and control group using simple random sampling. Further this design is explained through symbolic representation as under:

Where

$$
\begin{array}{llllll}
\mathbf{R} & \mathbf{E} & = & \mathbf{O 1} & \mathbf{T} & \mathbf{O 2} \\
\mathbf{R} & \mathbf{C} & = & \mathbf{O 3} & & \mathbf{O 4}
\end{array}
$$

$\mathrm{R}=$ Stands for Randomly selected $\quad \mathrm{E}=$ Stands for Experimental Group

$\mathrm{C}=$ Stands for Control Group $\quad \mathrm{O}=$ Stands for Observation or Measurement

$\mathrm{T}=$ Stands for experimental treatment

\section{Research Instrumentation and Data Collection}

As it was an experimental study therefore researchers choose pre-test post-test technique for data collection. In order to compare the academic achievement of students of both groups, two different questions papers were prepared in subject of chemistry for pre-test and post-test purpose. One paper was administered among the participants before treatment and the other paper was administered after the treatment. In this way, data was collected through pre-test and post-test technique.

\section{Data Analysis}

In order to analyze data statistically, raw scores of the both tests were organized and tabulated properly. Then statistical tools, i.e., means, standard deviation and t-tests were applied to draw the results.

\section{Selection of the Teachers for Experimental Process}

In order to perform experiment, two teachers possessing similar education and equal teaching experience were selected. Their qualifications were M.Sc Chemistry and B.Ed. They have been 
working in Elementary and Secondary Education Department Khyber Pakhtunkhwa (Pakistan) since 2003.

\section{INTERPRETATION OF DATA AND RESULTS}

The aim of the current research study was to examine the effect of over-scheduled involvement in co-curricular activities on the academic attainment of students at secondary school level. The current study was experimental in nature and pre-test posttest technique was used for data collection. Mean, standard deviation and t-tests were used for data analysis. The detail of statistical process is explained as under:

$H_{o}$ 1: There is no significant difference between the performance of control and experimental groups on pre-test.

Table 2: Indicating the significant of difference between the mean scores of control and experimental groups on Pre-Test

\begin{tabular}{lllllll}
\hline Groups & N & Mean & SD & SE & t-value & p-value \\
\hline Experimental & 25 & 67.24 & 1.13 & 0.31 & $\mathbf{0 . 3 9}$ & 0.70 \\
Control & 25 & 67.12 & 1.06 & & & \\
\hline
\end{tabular}

\begin{tabular}{llll}
\hline Non-Significant & df $=48 \quad(p>0.05)$ & table value of $t$ at 0.05 level $=2.011$
\end{tabular}

The statistical result of table 2 clearly indicates that calculated $t$ value $(t=0.39)$ was found less than the tabulated t value at 0.05 level of confidence. Therefore the statement is non-significant $(p=0.70>0.05)$. That's why the null hypothesis that "There is no significant difference between the performance of control and experimental groups on pre-test" is accepted. It shows that the students of both groups showed equal performance on pre-test. The statistical result is further explained through bar graph:

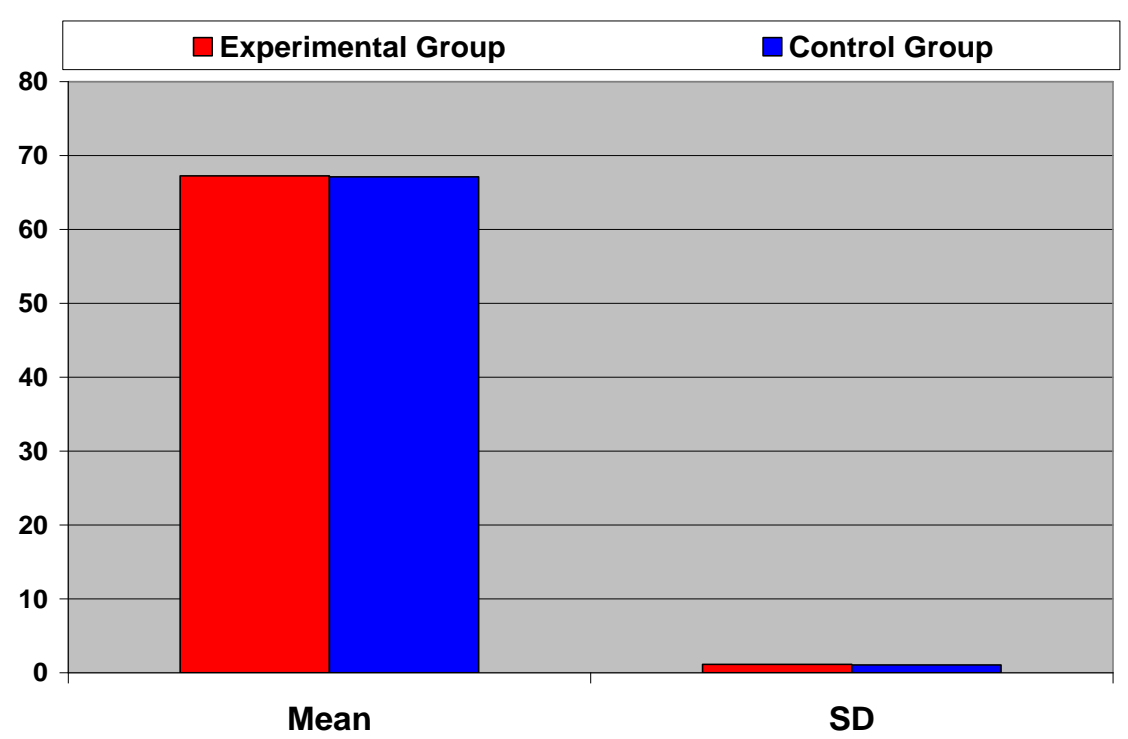

Fig.01: Showing the Mean and SD of Experiment and Control Groups on Pre-test 
$\mathrm{H}_{o}$ 2: There is no significant difference between the performance of control and experimental groups on post-test.

Table 3: Showing the significance of difference between the mean scores of control and experimental groups on Post-Test

\begin{tabular}{lllllll}
\hline Groups & N & Mean & SD & SE & t-value & p-value \\
\hline Experimental & 25 & 54.32 & 1.24 & 0.31 & $\mathbf{1 0 8 . 5 3 *}$ & 0.00 \\
Control & 25 & 88.36 & 0.96 & & & \\
\hline
\end{tabular}

*Significant $\quad$ df $=48 \quad(p<0.05) \quad$ table value of $t$ at 0.05 level $=2.011$

According to the statistical result of table 3, the calculated $t$ value $(t=108.53)$ was found greater than the tabulated $t$ value at 0.05 level of confidence. Therefore the statement is non-significant $(\mathrm{p}=0.00<0.05)$. Thus the null hypothesis that "There is no significant difference between the performance of control and experimental groups on post-test" is not accepted. It plainly indicates that the students of experimental group showed significantly disappointing and unsatisfactory performance as compared to the students of control group on post-test. The result of the study is further elaborated via bar graph:

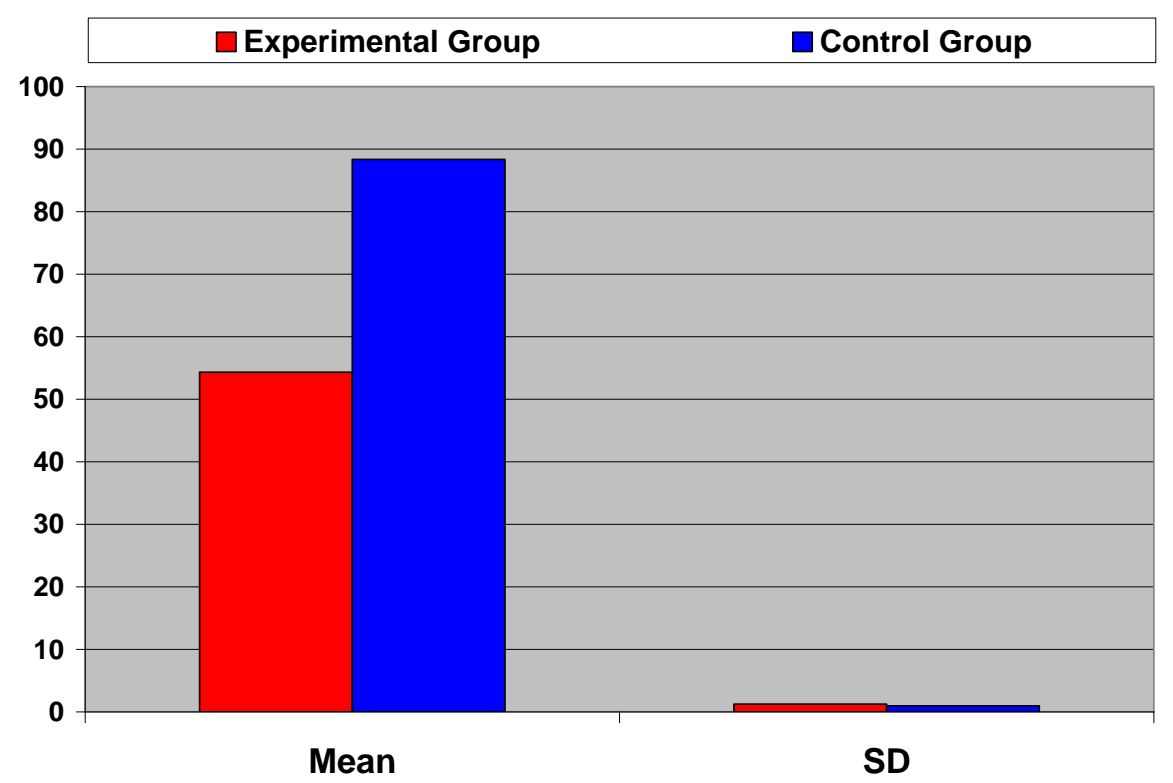

Fig. 02: Showing the Mean and SD of Experiment and Control Groups on Post-test

\section{DISCUSSION}

The current research study was conducted to examine the effects of over-scheduled involvement in co-curricular activities on the educational attainment of students studying in public secondary schools in Kohat Division, Pakistan. It was an experimental study and sample of fifty students was taken from Grade 10 of the Government High School Khurram, Karak based on simple random sampling technique. Furthermore, sample subjects were grouped into two groups i.e., control group and experimental group through pre-test scores. During the experiment, both the groups were taught in two separate rooms. Both the classrooms were equipped with similar facilities. Further they were involved in different co-curricular activities for 40 minutes daily in school. The students of experimental group were also involved for 2 hours after school time daily but the students of control group were not involved in any activity 
after school time. The experimental process was completed in six weeks. Then post-test was immediately done to investigate the academic achievement of the both groups. For this purpose the science teachers made a question paper in the four chapters of Chemistry which were taught during experimental process. This way data was collected, organized, tabulated, analyzed and compared.

The statistical results (table 2) of the current study plainly indicate that there is no significant difference between the mean scores of experimental (mean=67.24, $S D=1.13$ ) and control (mean $=67.12, S D=1.06)$ group on pre-test as the calculated t value $(t=0.39)$ was found less than the tabulated $\mathrm{t}(t=2.011)$ value at 0.05 level of confidence. Therefore the statement is non-significant $(p=0.70>0.05)$. That is why it is assumed that academic outcomes of students of the both groups were same on pre-test.

According to the statistical results of table 3 , it is clear that there is significant difference between the mean scores of experimental (mean $=54.32, S D=1.24)$ and control (mean=88.36, $S D=0.96)$ group on pre-test as the calculated t value $(t=108.53)$ was found greater than the tabulated $\mathrm{t}(t=2.011)$ value at 0.05 level of confidence. Therefore the statement is significant $(p=0.00<0.05)$. Therefore it is concluded that performance of the experimental group was unsatisfactory and disappointing as compared to the subjects of control group on post-test. Thus it is assumed that over-scheduled involvement in co-curricular activities has adverse affects on the academic achievement scores of the students.

\section{CONCLUSIONS}

In the light of statistical analysis and discussion, it was come to surface that there is significant negative effect of over-scheduled involvement in co-curricular activities on the academic achievement of students at secondary school level. The students of experimental group showed disappointing and unsatisfactory performance as they were involved over-scheduled in co-curricular activities after school time. On the other hand, the students of control group showed excellent performance as they were normally involved in co-curricular activities for only 40 minutes daily in school. They showed significant superiority over the students of experimental group. In nutshell, it was concluded that over-scheduled and extraordinary participation in co-curricular activities negatively and adversely affect student's academic achievement and lead toward low test scores.

\section{RECOMMENDATIONS}

In the light of statistical analysis and conclusion, some recommendations are made which are:

1. As it was come to light that over-scheduled involvement in co-curricular activities after school time negatively affects student's educational attainment. Therefore students should not be allowed for over-scheduled involvement in co-curricular activities after school time.

2. Proper periods should be reserved for co-curricular activities in school time table. Maximum three periods per week should be reserved for such activities as these activities are necessary for the balance personality of a child. In addition, involvement in co-curricular activities after school time should be banned.

3. Proper time table for academic as well as for co-curricular activities should be made for children at home so that they may develop well their self physically and academically. In addition, children should be kept busy through home tuition. 
4. Children may not be permitted to use DVDs, VCDs, camera mobiles, etc as these things are very harmful for students in young age. These things not only affect student's academic achievement but also affect their moral values. Therefore, it is strongly recommended that parents should not keep these things in home.

5. "A man is known by the company he keeps". This proverb clearly shows that a company of a student has a significant effect on its personality. Therefore students should not be the part of bad company.

\section{REFERENCES}

Ahamed, Y., MacDonald, H., Reed, K, Naylor, P. J., Liu-Ambrose, T. \& McKay, H. (2007). School-Based Physical Activity does not Compromise Children's Academic Performance. Medicine and Science in Sports and Exercise 2007;39: 371-376. American Educational Research Journal 1995; 32: 845-864.

Allison, B. (1979). Student Activities as the Ultimate Academic Department. NASSP Bulletin 63 (426): 95-98.

Ara, A. \& Saleem, R. (n. d). Role of Co-curricular Activities: Survey of the Perceptions of Stake Holders (Case Study of Peshawar District). Journal of Managerial Sciences, Vol: II, Number 2.

Coe, D. P., Pivarnik, J. M., Womack, C. J, Reeves, M. J. \& Malina, R. M. (2006). Effect of Physical Education and Activity Levels on Academic Achievement in Children. Medicine and Science in Sports and Exercise 2006;38:1515-1519.

Cooper, H., Valentine, J. C., Nye, B. \& Lindsay, J. J. (1999). Relationships between Five After-School Activities and Academic Achievement. .Journal of Education Psychology, 91 (2): 369-378.

Darling, N., Caldwell, L. L. \& Smith, R. (2005). Participation in School Based Extra-Curricular Activities and Adolescent Adjustment. Journal of Leisure Research, 37, 51-77.

Dollman, J., Boshoff, K. \& Dodd, G. (2006). The Relationship between Curriculum Time for Physical Education and Literacy and Numeracy Standards in South Australian Primary Schools. European Physical Education Review 2006;12:151-163.

Eccles, J. S. \& Barber, B. L. (1999). Student Council, Volunteering, Basketball, or Marching Band: What Kind Of Extracurricular Involvement Matters? Journal of Adolescent Research, 14 (1): 10-43.

Field, T., Diego, M. \& Sanders, C. E. (2001). Exercise is Positively Related to Adolescent's Relationships and Academics. Adolescence 2001;36:105-110.

Fredricks, J. \& Eccles, J. (2006). Is Extraordinary Participation Associated with Beneficial Outcomes? Concurrent and Longitudinal Relations. Developmental Psychology, 42(4), 698-713

Gardner, M., Roth, J. \& Brooks-Gunn, J. (2008). Adolescents' Participation in Organized Activities and Developmental Success 2 And 8 Years after High School: Do Sponsorship, Duration, and Intensity Matter? Developmental Psychology, 44(3), 814-830.

Hollar, D., Messiah, S. E., Lopez-Mitnik, G., Hollar, T. L., Almon, M. \& Agatston, A. S. (2010). Effect of a Two-Year Obesity Prevention Intervention on Percentile Changes in Body Mass Index and Academic Performance in Low-Income Elementary School Children. American Journal of Public Health 2010; 100:646.

Katozai, M. A. (2004). Preparation for the PCS screening Test of Senior English Teacher. University Publishers Shop \# 8-A Afghan Market, Qissa Khwani Peshawar. 
pp. 132-135

2014, Vol. 4, No. 3

Marais, P. (2011). The Significance of Student Teachers' Involvement in Co-Curricular Activities. International Journal for e-Learning Security (IJeLS), Volume 1, Issues 3(4). pp.81-88

Marsh, H. W. \& Kleitman, S. (2002). Extracurricular School Activities: The Good, the Bad, and the Nonlinear. Harvard Educational Review 72(4), 464-511

Mehmood, T., Hussain, T., Khalid, M. \& Azam, R. (2012). Impact of Co-curricular Activities on Personality Development of Secondary School Students. International Journal of Humanities and Social Science Vol. 2 No. 18; October 2012. pp. 139-145

Reeves, D. B. (2008). “The Extracurricular Advantage". Education Leadership, 86-87.

Suleman, Q., Aslam, H. D., Sarwar, S., Lodhi, M. A. \& Hussain, I. (2012). Factors Responsible for Unsatisfactory Academic Performance of the Secondary School Students in the Rural Areas of Kohat Division, Khyber Pakhtunkhwa (Pakistan). American Journal of Scientific Research, Issue 43 (2012), 46-57.

Sallis, J. F., McKenzie, T. L., Kolody, B., Lewis, M., Marshall, S. \& Rosengard, P. (1999). Effects of Health-Related Physical Education on Academic Achievement: Project SPARK. Research Quarterly For Exercise And Sport 1999; 70:127-134.

Shephard, R. J., Lavallee, H., Volle, M. \& La Barre. R. C. B. (1994). Academic Skills and Required Physical Education: The Trois Rivieres Experience. Canadian Association For Health, Physical Education, and Recreation Research Supplements; 1:1-12.

Thompson, D. (2008). Extracurricular that Count. Business Week Online. Retrieved from www.businessweekonline.com

Wagner, C. (1999). Improving the Prospects for Poor Children. The Futurist 33 (4). 